\title{
Risk analysis of construction diversion scheme
}

\author{
Yang Qingqing ${ }^{1, *}$ and Du Chengrong ${ }^{2}$ \\ ${ }^{1}$ Zhejiang Guangchuan Engineering Consulting Co., Ltd, Zhejiang Institute of Hydraulics \& Estuary, Hangzhou, Zhejiang, 310020 , \\ China \\ ${ }^{2}$ Delivery Center, Zhejiang Windey Co., Ltd, Hangzhou, Zhejiang, 311106, China
}

\begin{abstract}
The determination of diversion risk in the construction of water conservancy and hydropower projects is a key problem related to the guarantee of project safety, saving project investment, giving full play to benefits in advance and facilitating construction. According to the design data, considering the influence of the uncertain factors such as hydrology and hydraulics, this paper analyses the relationship between the elevation of the upstream cofferdam and the upstream design water level, uses the Monte Carlo method to simulate the construction flood process and the discharge capacity of the diversion buildings, makes statistical analysis and determines the risk corresponding to the upstream water level distribution of the cofferdam and the water retaining height of the cofferdam, and establishes the calculation model of the construction diversion risk.
\end{abstract}

\section{Preamble}

There are many uncertain factors in construction diversion, and there are many ways to study the risk rate of construction diversion. However, the application time of risk analysis in water conservancy and hydropower construction is relatively short, and the results have certain limitations. In the construction diversion planning of water conservancy and hydropower, people usually only regard the peak discharge as the uncertain factor, then select the construction diversion standard, diversion discharge and finally determine the diversion scheme according to the type and scale of the building. Obviously, only considering hydrological uncertainty is not comprehensive enough. In the construction diversion, in addition to the objective uncertainty of peak discharge, there are also uncertainties of hydraulic, structural and storage capacity, which will bring diversion risk $^{[1]}$. In this paper, Monte Carlo method is used to simulate the process of construction flood and the discharge condition of diversion buildings. The flood routing of construction flood is carried out through system simulation. The water level distribution in front of upstream cofferdam and the dynamic risk of cofferdam operation under different diversion standards are determined by statistical analysis model.

\section{Example calculation and analysis}

\subsection{Calculation model of diversion risk rate}

The total installed capacity of a hydropower project is $40 \mathrm{MW}$, its normal water storage level is $458.00 \mathrm{~m}$, the elevation of the dam top is $460.00 \mathrm{~m}$, and the total storage capacity is $934.63 \mathrm{~m}^{3}$. According to "Standard for rank classification and flood protection criteria of water and and hydropower projects (SL252-2017)", It belongs to small (I) type projects such as IV. According to " Specifications for construction planning of water resources and hydropower projects (SL303-2017) [2]", its diversion buildings are Class $\mathrm{V}$, and the corresponding diversion standards for earth-rock cofferdam design can adopt a flood return period of 5-10 years.

According to the division of the hydrological data for the time period, combined with the topographical geology, the layout of the hydraulic structure and the requirements of the diversion, a diversion scheme using cofferdams to block water during the dry season and flooding of the foundation pit during the flood season was preliminarily drawn up. The flood characteristics of each construction period are shown in Table 1, and the diversion flow of each diversion period is shown in Table 2. 
Table 1. Design Flood Information.

\begin{tabular}{|c|c|c|c|c|c|}
\hline \multirow{2}{*}{$\begin{array}{l}\text { Period } \\
\text { (month) }\end{array}$} & \multirow{2}{*}{$\begin{array}{l}\text { Average flow rate } \\
\left(\mathrm{m}^{3} / \mathrm{s}\right)\end{array}$} & \multirow[b]{2}{*}{$\mathrm{Cv}^{\mathrm{a}}$} & \multirow[b]{2}{*}{$\mathrm{Cs} / \mathrm{Cv}^{\mathrm{b}}$} & \multicolumn{2}{|c|}{$\begin{array}{c}\text { Frequency design flow } \\
\text { rate }\left(\mathrm{m}^{3} / \mathrm{s}\right)\end{array}$} \\
\hline & & & & $\mathrm{P}=10.0 \%$ & $\mathrm{P}=20.0 \%$ \\
\hline 1 & 41.8 & 0.26 & 4 & 56.4 & 50.4 \\
\hline 2 & 65.3 & 0.62 & 4 & 112.0 & 84.4 \\
\hline 3 & 113.0 & 0.65 & 4 & 203.0 & 149.0 \\
\hline 4 & 263.0 & 0.65 & 4 & 491.0 & 375.0 \\
\hline 5 & 457.0 & 0.56 & 4 & 795.0 & 630.0 \\
\hline $6 \sim 9$ & 1910.0 & 0.54 & 4 & 3230.0 & 2510.0 \\
\hline 10 & 307.0 & 0.65 & 4 & 577.0 & 430.0 \\
\hline 11 & 172.0 & 0.70 & 4 & 324.0 & 241.0 \\
\hline 12 & 62.3 & 0.28 & 4 & 85.1 & 75.6 \\
\hline
\end{tabular}

a $\mathrm{Cv}$ - The ionization coefficient of $P$ - III distribution.

${ }^{\mathrm{b}} \mathrm{Cs}$ - The dispersion coefficient of $P$ - III distribution.

Table 2. Diversion flow in each period.

\begin{tabular}{lccc}
\hline Diversion period & Period(month) & $\mathrm{Q}_{20 \%}\left(\mathrm{~m}^{3} / \mathrm{s}\right)$ & $\mathrm{Q}_{10 \%}\left(\mathrm{~m}^{3} / \mathrm{s}\right)$ \\
\hline Initial diversion & $11 \sim 4$ & 375 & 491 \\
flood season & $6 \sim 9$ & 2510 & 3230 \\
Late stage & $10 \sim 5$ & 630 & 795 \\
\hline
\end{tabular}

\subsection{Diversion and discharge capacity}

In the initial period, the river bed is narrow for discharge. In the flood season, the river bed on the left bank and the bottom hole of the open scouring bar section are used to discharge the flood, and the 2 holes with the bottom holes of $6 \mathrm{~m} \times 10 \mathrm{~m}$ are arranged at the later scouring bottom hole section for discharge.

Hydraulic parameters of discharge, The flow rate coefficient factor is subject to the triangular distribution, and the values of the three parameters in each period are shown in Table 3.

Table 3. Parameter value table of flow rate coefficient.

\begin{tabular}{llccc}
\hline \multicolumn{1}{c}{ Diversion programme } & Upper limit & Median & Lower limit \\
\hline Initial diversion & $\begin{array}{l}\text { Downstream } \\
\text { desilting(poor) }\end{array}$ & 0.385 & 0.367 & 0.356 \\
$\begin{array}{l}\text { Flood season } \\
\text { diversion }\end{array}$ & $\begin{array}{l}\text { Downstream } \\
\text { desilting(fair) } \\
\text { downstream } \\
\text { dredging(good) }\end{array}$ & 0.270 & 0.172 & 0.074 \\
$\begin{array}{l}\text { Downstream } \\
\text { desilting(poor) }\end{array}$ & 0.385 & 0.313 & 0.270 \\
$\begin{array}{l}\text { Later } \\
\text { diversion }\end{array}$ & $\begin{array}{l}\text { Downstream } \\
\text { desilting(fair) } \\
\text { downstream } \\
\text { dredging(good) }\end{array}$ & 0.378 & 0.367 & 0.356 \\
\hline
\end{tabular}

\subsection{Calculation results and analysis of diversion} risk

According to the empirical formula of the traditional method, without considering the influence of random

Table 4. Risk rate of water level in front of cofferdam.

\begin{tabular}{lcccr}
\hline \multicolumn{1}{c}{ Diversion period } & $\begin{array}{c}\text { Maximum } \\
\text { upstream } \\
\text { flood } \\
\text { frequency P }\end{array}$ & $\begin{array}{c}\text { Maximum } \\
(\mathrm{m})\end{array}$ & $\begin{array}{c}\text { Mascharge } \\
\left(\mathrm{m}^{3} / \mathrm{s}\right)\end{array}$ & Risk rate R \\
\hline Initial diversion & $10 \%$ & 432.254 & 491 & 0.0513 \\
Flood season diversion & $20 \%$ & 431.340 & 375 & 0.1056 \\
& $10 \%$ & 438.282 & 3230 & 0.0513
\end{tabular}




\begin{tabular}{lrrrr} 
& $20 \%$ & 436.613 & 2510 & 0.1056 \\
& $10 \%$ & 438.999 & 795 & 0.0513 \\
later diversion & $20 \%$ & 437.419 & 630 & 0.1056 \\
\hline
\end{tabular}

Considering the random factors of hydrology and simulation of the power station at various periods are hydraulics, the calculation results of the diversion shown in the table. Table 5, table 6.

Table 5. Design water level risk of initial diversion.

\begin{tabular}{ccccc}
\hline $\begin{array}{c}\text { flood } \\
\text { frequency } \\
(\%)\end{array}$ & $\begin{array}{c}\text { Design } \\
\text { Water Level } \\
(\mathrm{m})\end{array}$ & $\begin{array}{c}\text { Expansion of } \\
\text { excavation }\end{array}$ & Risk rate R & $\begin{array}{c}\text { Guaranteed } \\
\text { rate P }\end{array}$ \\
\hline \multirow{3}{*}{$10 \%$} & 432.254 & Fully excavation & 0.242 & 0.758 \\
& & $50 \%$ excavation & 0.279 & 0.721 \\
& & $10 \%$ Expansion & 0.421 & 0.579 \\
$20 \%$ & 431.34 & Fully excavation & 0.520 & 0.480 \\
& & $50 \%$ excavation & 0.626 & 0.374 \\
& & $10 \%$ Expansion & 1.000 & 0.000 \\
\hline
\end{tabular}

Table 6. Results of design water level risk in flood season and later stage.

\begin{tabular}{|c|c|c|c|c|c|}
\hline $\begin{array}{c}\text { Diversion } \\
\text { period }\end{array}$ & $\begin{array}{c}\text { Design flood } \\
\text { frequency } \\
(\%) \\
\end{array}$ & $\begin{array}{c}\text { Design } \\
\text { Water Level } \\
(\mathrm{m})\end{array}$ & $\begin{array}{l}\text { Downstream } \\
\text { desilting status }\end{array}$ & $\begin{array}{c}\text { Risk rate } \\
\text { R }\end{array}$ & $\begin{array}{c}\text { Guaranteed } \\
\text { rate P }\end{array}$ \\
\hline \multirow{6}{*}{$\begin{array}{l}\text { flood } \\
\text { season }\end{array}$} & \multirow{3}{*}{$10 \%$} & \multirow{3}{*}{438.282} & Poor & 0.598 & 0.402 \\
\hline & & & General & 0.231 & 0.769 \\
\hline & & & Good & 0.145 & 0.855 \\
\hline & \multirow{3}{*}{$20 \%$} & \multirow{3}{*}{436.613} & Poor & 1.000 & 0.000 \\
\hline & & & General & 0.507 & 0.493 \\
\hline & & & Good & 0.285 & 0.715 \\
\hline \multirow{6}{*}{$\begin{array}{l}\text { Late } \\
\text { stage }\end{array}$} & \multirow{3}{*}{$10 \%$} & \multirow{3}{*}{438.999} & Poor & 0.349 & 0.651 \\
\hline & & & General & 0.321 & 0.679 \\
\hline & & & Good & 0.257 & 0.743 \\
\hline & \multirow{3}{*}{$20 \%$} & \multirow{3}{*}{437.419} & Poor & 0.587 & 0.413 \\
\hline & & & General & 0.527 & 0.473 \\
\hline & & & Good & 0.480 & 0.520 \\
\hline
\end{tabular}

Calculations proves that:

(1) As far as the same hydrological and hydraulic conditions are concerned, when the corresponding design frequencies are $10 \%$ and $20 \%$, the risk of cofferdam water retaining during the initial, flood and later diversions considering random factors is 0.242 , $0.520,0.116,0.257,0.223$ and 0.444 are greater than the risk calculated by traditional methods of $0.0513,0.1056$, so considering the influence of random factors can be more reasonable and clear to design the risk facing the cofferdam.

(2) According to the calculation of the initial diversion risk rate, when the completion rate of expansion is reduced from $100 \%$ to about $50 \%$, the increase in the risk rate of cofferdam water retention is relatively small, from 0.242 to 0.279 , and when the expansion is completed, When the rate is below $50 \%$, the cofferdam risk rate increases significantly, from 0.279 to 0.421 .

(3) Through the calculation of flood diversion and later diversion risk rates, it can be known that when the dredging rate is $100 \%$ to $85 \%$, the cofferdam water retention risk rate increases relatively smoothly, and when the dredging rate is less than $85 \%$ The risk rate of cofferdam water retention will increase sharply.

\section{Summary}

Based on the Monte-Carlo method, this paper simulates the construction flood inflow process and the analysis of the diversion of the diversion buildings, which shows that it is necessary to consider the influence of various uncertain factors in the calculation of the comprehensive risk of construction diversion. Computational analysis shows that after considering hydraulic uncertainties, the comprehensive risk of the system increases by about $20 \%$. At the same time, this paper also analyzes the impact of changes in expansion and downstream dredging on the risk rate of cofferdam water retention. The risk has also increased by about 5\% to $10 \%$. Therefore, in establishing the calculation model of construction diversion risk, the uncertain factors to which the construction system is subjected should be fully considered. 


\section{References}

1. Hu Zhigen, Liu Quan. (2002) Risk analysis of water retaining and diversion of earth-rock cofferdam based on Monte-Carlo method. Advances in Water Science,636-638.
2. Ministry of Water Resources of the PRC,(2017), Specifications for construction planning of water resources and hydropower projects (SL303-2017). China Water Resources and Hydropower Press, Beijing. 